\title{
Afscheid van dezen en genen?
}

Citation for published version (APA):

Geraedts, J. P. M. (2013). Afscheid van dezen en genen? Afscheidsrede van Prof. dr. Joep Geraedts. (1 ed.) Universiteit Maastricht. https://doi.org/10.26481/spe.20130426jg

Document status and date:

Published: 26/04/2013

DOI:

10.26481/spe.20130426jg

Document Version:

Publisher's PDF, also known as Version of record

\section{Please check the document version of this publication:}

- A submitted manuscript is the version of the article upon submission and before peer-review. There can be important differences between the submitted version and the official published version of record.

People interested in the research are advised to contact the author for the final version of the publication, or visit the DOI to the publisher's website.

- The final author version and the galley proof are versions of the publication after peer review.

- The final published version features the final layout of the paper including the volume, issue and page numbers.

Link to publication

\footnotetext{
General rights rights.

- You may freely distribute the URL identifying the publication in the public portal. please follow below link for the End User Agreement:

www.umlib.nl/taverne-license

Take down policy

If you believe that this document breaches copyright please contact us at:

repository@maastrichtuniversity.nl

providing details and we will investigate your claim.
}

Copyright and moral rights for the publications made accessible in the public portal are retained by the authors and/or other copyright owners and it is a condition of accessing publications that users recognise and abide by the legal requirements associated with these

- Users may download and print one copy of any publication from the public portal for the purpose of private study or research.

- You may not further distribute the material or use it for any profit-making activity or commercial gain

If the publication is distributed under the terms of Article $25 \mathrm{fa}$ of the Dutch Copyright Act, indicated by the "Taverne" license above, 


\section{Maastricht University}

Afscheidsrede

Prof. dr. J oep Geraedts

Faculty of Health, Medicine and Life Sciences

\section{Afscheid van dezen en genen?}




\title{
Afscheid van dezen en genen?
}

\author{
Afscheidsrede \\ Prof. dr.Joep Geraedts
}

Maastricht, 26 april 2013 
Mijnheer de Rector Magnificus,

Gewaardeerde toehoorders uit de universitaire gemeenschap, het academisch

ziekenhuis, vrienden, kennissen en familie,

Dames en heren,

Bij een afscheid hoort een terugblik op alles wat er door de jaren heen is gebeurd, maar daar mag het niet bij blijven. Een geneticus hoort zowel naar Dezen en Genen van de vorige generaties, de huidige als de toekomstige te kijken. Dezen zijn de personen die in mijn leven een belangrijke rol hebben gespeeld. Ik zal me daarbij beperken tot de klinische genetica. Dit vakgebied houdt zich bezig met het bestuderen van verschillen in aanleg die tot ziekte bij de mens kunnen leiden en de manier waarop deze verschillen van de ene generatie naar de volgende worden doorgegeven. Zowel op het gebied van de klinische genetica als dat van de menselijke voortplanting is de vooruitgang gedurende de laatste 40 jaar ongekend geweest. Om dat duidelijk te maken hoef ik alleen maar te verwijzen naar twee begrippen die iedereen kent: DNA en IVF.

Op 25 april 1953 werd de structuur van het DNA gepubliceerd door Watson en Crick. Heel toevallig was dat gisteren op de dag af 60 jaar geleden(1). Vanaf dat moment heeft de genetica een hoge vlucht genomen.

Het DNA is verpakt in microscopisch zichtbare eenheden: de chromosomen. Pas in 1956 werd duidelijk dat de mens 46 chromosomen heeft(2).Van de 23 paren is telkens een chromosoom van de moeder en het andere van de vader afkomstig.

In 1959 werd vastgesteld dat er bij kinderen met Down syndroom een extra chromosoom 21 aanwezig is (3). In bijna alle gevallen is er een chromosoom te veel in de eicel terecht gekomen.

Sindsdien zijn door steeds verfijndere technieken meer en meer verschillende, ook structurele afwijkingen van de chromosomen aan het licht gebracht.

Het ontrafelen van de oorzaak van veel erfelijke aandoeningen heeft zich ontwikkeld van het spreekwoordelijke zoeken van de speld in een hooiberg naar de analyse van de volledige encyclopedie van het erfelijke materiaal en dat ook nog eens voor een acceptabele prijs.

Aanvankelijk werd in het laboratorium vooral chromosoomonderzoek gedaan waarmee microscopisch zichtbare veranderingen konden worden vastgesteld. Momenteel vindt veel vaker DNA onderzoek plaats om veranderingen van een of enkele baseparen, de bouwstenen van het DNA aan te tonen of uit te sluiten.

In dit verband is het goed om stil te staan bij de enorme hoeveelheid informatie die aanwezig is in de kern van iedere cel. De 23 paren chromosomen die elk tijdens de celdeling onder het mikroskoop maar enkele duizendste millimeter groot zijn bevatten samen ongeveer 2 meter DNA. Deze biedt plaats aan niet minder dan 3 miljard baseparen. Wanneer we uitgaan van 3000 letters per pagina hebben we 1.000.000 pagina's nodig om de totale hoeveelheid informatie die aanwezig is in één cel op te slaan. Vaak is een verandering van een of enkele van de bouwstenen van de genetische code voldoende om een ernstige ziekte te veroorzaken.

Het is nu mogelijk om relatief goedkoop en snel de coderende gedeelten van alle 22.000 menselijke genen te sequencen zoals onze Nijmeegse collega's onlangs hebben laten zien (4).

In 1966 verscheen de eerste druk van een beroemde catalogus van Victor McKusick met daarin de erfelijke eigenschappen van de mens. Sinds 1988 is er een online versie, met 
daarin momenteel niet minder dan 20.000 humane genen en kenmerken die volgens de wetten van Mendel overerven (5). Van vele duizenden genen zijn nu de ziekte veroorzakende mutaties bekend.

Door al deze ontdekkingen heeft de genetica in de $20^{\text {ste }}$ eeuw steeds meer betekenis gekregen. Maar behalve door toename van de kennis, komt dat ook door het verdwijnen van veel infectieziekten en voedingsproblemen die aan het begin van de vorige eeuw nog voor veel kinderziekten en sterfte zorgden. Momenteel veroorzaken erfelijke ziekten en aangeboren afwijkingen naar schatting bijna de helft van de totale kindersterfte in Nederland. De klinische genetica heeft zich als discipline dan ook vooral vanuit de kindergeneeskunde ontwikkeld. Maar ook bij volwassenen is er steeds meer vraag naar advies vanwege het voorkomen van kanker, hart- en vaatziekten, hersenaandoeningen of huidziekten in de familie. Steeds meer komen ook complexe aandoeningen in beeld. Deze zijn complex omdat het niet alleen om mutaties van individuele genen gaat maar om het samenspel tussen meerdere genen en de samenhang tussen de erfelijke aanleg en de invloed van omgevingsfactoren op de manier waarop de genen tot uiting komen. Dit is het terrein van het nieuwe vakgebied dat epigenetica wordt genoemd.

\section{Klinisch genetische centra}

Toen in de tweede helft van de twintigste eeuw steeds meer kennis beschikbaar kwam over erfelijke ziekten en deze toepasbaar bleek in de klinische praktijk werden in ons land rond het jaar 1980 in de nabijheid van de academische ziekenhuizen stichtingen klinische genetica opgericht. Dit gebeurde op grond van een in 1977 verschenen advies van de Gezondheidsraad (6). Hierin werd gewezen op het grote medische en maatschappelijke belang van de diagnostiek en preventie van erfelijke aandoeningen en de voorlichting hierover.

Voorafgaande aan de oprichting van de centra was er wel al een ontwikkeling geweest van klinische activiteiten, vooral in de afdelingen kindergeneeskunde en obstetrie/ gynaecologie van de academische ziekenhuizen. Tevens had veelal in universitaire laboratoria ontwikkeling van diagnostiek plaatsgevonden. Met de oprichting van de stichtingen werd het mogelijk de genetische activiteiten te bundelen en regulier te financieren via de zorgverzekering. De opgerichte stichtingen maakten het voor de ziektekostenverzekeraars gemakkelijk jaarlijks te controleren waaraan de middelen werden besteed. Wanneer de klinisch genetische centra vanaf de start in de academische ziekenhuizen zouden zijn ondergebracht zou de groei belemmerd zijn geweest. Ongeveer 10 jaar geleden zijn de meeste stichtingen geïntegreerd in de academische ziekenhuizen en daarmee ziekenhuisafdelingen geworden, zo ook in Maastricht.

Dat was ongeveer 20 jaar na de oprichting van de Stichting Klinische Genetica Limburg (SKGL) in 1981 naar het voorbeeld van de Rotterdamse stichting. Dit had vooral te maken met de aanwezigheid van Prof. Hans Galjaard uit Rotterdam als een van de externe adviseurs. De andere was Ben ter Haar uit Nijmegen. Ter Haar had zichzelf opgeleid tot een van de eerste klinisch genetici van Nederland en gaf leiding aan de eerste multidisciplinair samengestelde werkgroep erfelijkheidsadviezen. Naar dit model werd ook in Maastricht een dergelijke werkgroep opgericht, waaruit later de polikliniek is ontstaan.

Ter Haar was hiervan adviseur en werd tevens opleider van Christine de Die. Dr. Connie Stumpel volgde dr. Liesbeth Siderius op als kinderarts en werd door Prof. Jean-Pierre 
Fryns uit Leuven opgeleid. In 1988 werd Jean-Pierre Fryns ook in Maastricht benoemd tot hoogleraar. In 1989 werd gestart met een polikliniek in het St. Maartens Gasthuis te Venlo. Ieder jaar breidde de dienstverlening zich uit over een groter gebied van de provincie Limburg. Vanaf 1998 werd door de fusie met de Noord-Brabantse stichting, de SENB, ook de regio Zuidoost Brabant aan het verzorgingsgebied toegevoegd, met een eigen vestiging, die na een interne verhuizing en uitbreiding twee weken geleden in het Máxima Medisch Centrum in Veldhoven feestelijk is heropend.

De aantallen adviesvragen hebben zich in de loop der jaren gestaag uitgebreid. In 2012 bedroeg het totale aantal verwijzingen ongeveer 5000, waarbij het in ongeveer een-derde van de gevallen om een enkelvoudige erfelijkheidsadvisering ging en in de overige gevallen om een complexe vraagstelling.

\section{Cytogenetica}

Naast de polikliniek kent de afdeling een drietal laboratoria. Het oudste is het cytogenetica laboratorium. Voordat de SKGL werd opgericht waren er in de provincie Limburg niet minder dan vijf fylogenetische laboratoria, dat wil zeggen laboratoria waar (ook) chromosoomonderzoek werd uitgevoerd. Het oudste bevond zich sinds 1962 in Ziekenhuis St. Anaal te Maastricht. Verder waren er laboratoria operationeel in de ziekenhuizen te Sittard en Roermond, in Venray (binnen de Stichting Ziekenhuisapotheek en Klinisch Laboratorium) en Otters (in de instelling Maria Roefpan). Aan dit laboratorium was de enige full time cytogenetica verbonden. Dat was Drs. Guus Hamers die in 1983 overkwam naar Maastricht samen met de analiste Gerrie Peeters.

Sinds de fusie van de SKGL met de SENB is er sprake van een cytogenetica laboratorium op twee locaties: Maastricht en Veldhoven. De productie bedroeg in 2012 ongeveer 5000 genotyperingen, waarvan ongeveer 4000 postnataal en 1000 prenataal.

\section{Het Laboratorium voor Erfelijke Metaboliet Ziekten}

Op 1 augustus 1983 werd Dr. Leo Spaaien uit Utrecht aangetrokken voor de biochemische basisdiagnostiek. De eerder deze maand overleden Prof. Syb Wadman van het Wilhelmina Kinderziekenhuis in Utrecht verklaarde zich bereid hem in te werken in deze diagnostische discipline en de opzet van het daarvoor noodzakelijke laboratorium vanuit Utrecht voor te bereiden en te begeleiden. Jaap Bakker kwam uit Rotterdam als eerste analist.

In 1985 kon daadwerkelijk worden begonnen met de diagnostiek van erfelijke stofwisselingsziekten. Dit bleef aanvankelijk voornamelijk beperkt tot de biochemische basisdiagnostiek. Later werden grote aantallen patiënten onderzocht met behulp van de methionine belastingstest om hyperhomocysteïnemie aan te tonen.

De productie in 2012 bedroeg ongeveer 2000 onderzoeken. In ongeveer 800 gevallen ging het om biochemische basisdiagnostiek en in ongeveer 1000 om enzymdiagnostiek.

\section{Clinical Genomics}

Aan het einde van de jaren ' 80 werd tenslotte een begin gemaakt met de DNAdiagnostiek door de overkomst van Dr. Henk Meijer van de Maastrichtse groep Microbiologie en het aantrekken van de analiste Roselie Jongbloed uit Nijmegen. Na de verhuizing naar het Drie-X-gebouw op het Randwyckterrein begon kon het pakket verrichtingen pas echt goed worden ontwikkeld. In 1995 ging de DNA-diagnostiek officieel van start, door de toekenning van een subsidie van de Ziekenfondsraad. 
In 1996 werd Dr. Bert Smeets uit Nijmegen aangetrokken. Hij volgde Henk Meijer op bij diens vertrek als laboratoriumhoofd in 1999. Gedurende de daaropvolgende jaren werd de DNA-diagnostiek gestaag uitgebouwd. In 2001 werd het Genoomcentrum opgericht en in 2008 vond een versmelting plaats van de unit DNA-diagnostiek en het Genoomcentrum tot Clinical Genomics. Het aantal verrichtingen is zeer sterk toegenomen en bedroeg in 2012 meer dan 7000.

\section{Prenatale diagnostiek}

Zodra tijdens de erfelijkheidsadvisering naar voren komt dat er sprake een verhoogd risico op een kind met een erfelijke aandoening is er slechts een klein aantal alternatieven om het verhoogde risico weg te nemen. Naast het afzien van zwangerschap of het opteren voor donor ei- of zaadcellen zijn prenatale diagnostiek of preimplantatie genetische diagnostiek de enige twee opties.

$\mathrm{Al}$ in het midden van de 50er jaren van de vorige eeuw werd door de Deense onderzoekers Fritz Fuchs en Povl Riis een begin gemaakt met het onderzoek tijdens de zwangerschap (7). Vooral door de activiteiten van Prof. Galjaard in Rotterdam werd de prenatale diagnostiek in Nederland geïntroduceerd.

Om een vruchtwaterpunctie te kunnen uitvoeren dient gewacht te worden tot de $16 \mathrm{e}$ week van de zwangerschap. Het laboratorium onderzoek duurt vervolgens ook nog een paar weken. Dit betekent dat de uitslag meestal niet voor de 18 e of 19 e week van de zwangerschap beschikbaar is. Dit is extreem laat met het oog op een eventuele afbreking van de zwangerschap, waarvoor dan een ziekenhuisopname noodzakelijk is.

Prenatale diagnostiek brengt bovendien het risico met zich mee dat de zwangerschap wordt beëindigd door de ingreep. Tevens is er een beperkt budget beschikbaar voor dit onderdeel van de gezondheidszorg. Om deze redenen mag prenatale diagnostiek alleen op indicatie plaatsvinden.

In 1983 waren er slechts drie centra in Nederland die zich bezighielden met het genetisch onderzoek van de ongeboren vrucht. Deze waren gesitueerd in Rotterdam, Amsterdam en Groningen. Dit betekende dat geen enkele zwangere in Nederland voor deze vorm van diagnostiek verder moest reizen dan haar lotgenoten uit Zuid-Limburg. Nog voor de opstart van de activiteiten van de SKGL werden daarom al gesprekken gevoerd om te bereiken dat in Maastricht het volgende prenatale centrum van Nederland zou worden gevestigd.

Het heeft nog tot 22 november 1985 geduurd tot de zozeer gewenste vergunning voor prenatale diagnostiek werd verleend en Maastricht het vierde centrum in Nederland werd. De aankondiging in de Limburger was het startpunt van een reeks ingezonden brieven.

Het tere punt was de mogelijkheid van selectieve abortus, die in het artikel werd genoemd. We mogen niet vergeten dat pas enkele jaren eerder, in 1981, de abortusdiscussie in Nederland ten einde was gekomen door het aannemen van een abortuswet (9). Voor het uitvoeren van de prenatale diagnostiek diende het ziekenhuis een vergunning in het kader van deze wet aan te vragen. Het ziekenhuis St. Annadal in Maastricht beschikte hierover maar in de regio Zuidoost Brabant was hiervoor in geen van de ziekenhuizen voldoende draagvlak. Om uit de impasse te komen werd er een samenwerkingsovereenkomst gesloten met het Diagnostisch Centrum Eindhoven, het latere Diagnostiek voor U, en de Regionale Gynaecologenvereniging Zuidoost Brabant, zodat de diagnostiek in die regio toch van start kon gaan. Dr. Jules Keizer en Drs. Diederik Veersema zijn nog steeds de drijvende krachten achter deze jarenlange samenwerking. 


\section{Het diagnostisch onderzoek}

Prenatale diagnostiek betreft het onderzoek van de chromosomen, de genen en andere eigenschappen van het kind in een vroeg stadium van de zwangerschap. Deze vorm van diagnostiek is op de eerste plaats van belang voor paren die al eerder zelf of in hun gezin of familie geconfronteerd werden met een gendefect of een chromosomale afwijking. Deze mensen hebben vaak op basis van de mogelijkheid van prenatale diagnostiek gekozen voor een (volgende) zwangerschap, terwijl ze zonder dit alternatief afgezien zouden hebben van (verdere) kinderen. In de loop der jaren zijn hiervoor diverse methoden ontwikkeld. In 1983 is de vlokkentest aan het arsenaal toegevoegd (10). Vooral door de invoering van het diagnostisch ultrageluidonderzoek en moleculaire diagnostiek heeft het vakgebied van de prenatale diagnostiek in de laatste 25 jaar een enorme ontwikkeling doorgemaakt.

In Nederland zijn er jaren geweest dat meer dan 13.000 keer een vruchtwateronderzoek of vlokkentest werd verricht. Sindsdien is dit aantal afgenomen. In Maastricht is dezelfde tendens waarneembaar. De afname kan verklaard worden door de invoering van de combitest (11). Bij deze niet invasieve test wordt op basis van meerdere kenmerken zoals de leeftijd van de moeder, circulerende eiwitten in het bloed van de moeder en nekplooimetingen van de vrucht, een individueel risico berekend. Wanneer dit te groot is dient door vervolgonderzoek vlokkentest of vruchtwaterpunctie de aanwezigheid van Downsyndroom aangetoond of uitgesloten te worden.

Onlangs hebben Drs. Elke Mersy en Dr. Suzanne Frints laten zien dat de genetische methode waarbij de DNA code van de vrucht in het moederlijk bloed afgelezen wordt, zoals deze al commercieel wordt aangeboden in het buitenland, Downsyndroom kan uitsluiten zonder invasieve ingreep (12). Als gevolg daarvan zullen in de toekomst alleen nog vruchtwaterpuncties nodig zijn wanneer de bloedtest aangeeft dat het ongeboren kind Downsyndroom heeft. Hierdoor zijn er veel minder puncties nodig. Een landelijk consortium is momenteel een WBO vergunning aan het opstellen zodat deze test beschikbaar kan worden gesteld aan alle hoog risico zwangeren in Nederland.

\section{IVF}

Tijdens mijn promotieonderzoek in Leiden in 1974 woonde ik een lezing bij van Bob Edwards, die zijn pogingen beschreef om bij de mens reageerbuisbevruchting tot stand te brengen. Veel toehoorders maakten daar destijds erg schampere opmerkingen over. Zij konden niet geloven dat vier jaar later Louise Brown als eerste IVF baby zou worden geboren (13) en dat er nu al meer dan vijf miljoen IVF-kinderen zijn. Voor mij is Bob Edwards daarom een icoon, die in 2010 te laat maar zeer terecht met de Nobelprijs werd geëerd. Het toeval of misschien wel het noodlot wil dat hij letterlijk vanmiddag wordt begraven in Cambridge.

\section{IVF in Maastricht}

Kort na mijn komst naar Maastricht werd ik door Prof.Jelte de Haan en (toen nog) Dr. Hans Evers benaderd met de vraag om ook een IVF laboratorium in Maastricht op te starten. Omdat zich toevallig op hetzelfde moment een werkzoekende bioloog meldde in de persoon van drs. John Dumoulin kon aan het verzoek van de heren gynaecologen op redelijk korte termijn tegemoet gekomen worden. De in het ziekenhuis verkregen eicellen werden vervolgens naar het Biomedisch Centrum van de Rijksuniversiteit Limburg gebracht om bevrucht te worden. Het waren spannende tijden, niet alleen omdat het wachten was op de eerste zwangerschap, maar ook op de regelgeving die 
voor de IVF in Nederland zou gaan gelden. Uiteindelijk werd Maastricht erkend als een van de 13 Nederlandse IVF centra.

Niemand kon in die beginjaren vermoeden dat de kans op een levendgeboren kind per gestarte behandeling nog eens meer dan $30 \%$ zou bedragen.

In Nederland zijn in 2011 bijna 5.000 baby's geboren na IVF. Dit betekent dat één op de 37 baby's in Nederland een IVF-kind was. De toename van de kans op een zwangerschap is vooral te danken aan de betere resultaten die zijn behaald met embryo's die ingevroren zijn bewaard. Het totaal aantal zwangerschappen dat voortkomt uit een zogeheten cryo-cyclus bedroeg in 2011 ongeveer een kwart van het totale aantal zwangerschappen na IVF (14).

In 2002 werd in Maastricht de geboorte van het 1000ste IVF kind gevierd.

Dat aantal is inmiddels toegenomen tot 2674 kinderen, 1855 uit een eenlingzwangerschap, 774 uit een tweelingzwangerschap en 45 uit drielingzwangerschap.

Het Maastrichtse IVF laboratorium is al heel lang geen onderdeel meer van de klinische genetica. Toch is er nog altijd sprake van een heel nauwe relatie. Deze komt door de samenwerking van de afdelingen Voortplantingsgeneeskunde en het IVF laboratorium met de afdeling Klinische Genetica op het gebied van de Pre-implantatie Genetische Diagnostiek (PGD) en op het gebied van het wetenschappelijk onderzoek.

We hopen dat die samenwerking structureel verankerd gaat worden door de instelling van het specialty EVA.

\section{PGD}

Door het feit dat in twee aangrenzende ruimtes van ons laboratorium zowel IVF als prenatale diagnostiek werden uitgevoerd, ontstond in 1985 het idee om PGD oftewel embryoselectie te gaan ontwikkelen. PGD is een alternatief voor paren die prenatale diagnostiek afwijzen vanwege de daarmee samenhangende selectieve abortus. Bij PGD vindt de selectie plaats voordat de embryo's naar de baarmoeder worden gebracht en er sprake is van een zwangerschap. Het genetisch onderzoek wordt enkele dagen na de bevruchting uitgevoerd. Deze bevruchting moet daarom door middel van IVF gebeuren. Veel patiënten hebben echter geen IVF nodig want ze zijn niet onvruchtbaar.

Na drie dagen bestaat het embryo uit ongeveer acht cellen, waarvan er meestal een wordt afgenomen voor het laboratoriumonderzoek. Alleen embryo's zonder de afwijking waarvoor er een verhoogde kans op ziekte is, komen in aanmerking voor plaatsing in de baarmoeder.

In 1997 werd het eerste Nederlandse kind geboren na toepassing van PGD. In januari 2003 heeft de Staatssecretaris van VWS, mevrouw Ross-van Dorp een nieuwe planningsregeling klinisch genetisch onderzoek en erfelijkheidsadvisering vastgesteld (15). Het Maastrichtse centrum heeft bij die gelegenheid als eerste en enige centrum in Nederland vergunning gekregen voor het toepassen van PGD.

Het MUMC+beschikt over geheel geprotocolleerde overeenkomsten voor transport PGD met het Universitair Medisch Centrum Utrecht, het UMCG in Groningen en binnenkort het AMC in Amsterdam. Dit bespaart een aantal wensouders lange (en veelvuldige) reizen naar Maastricht. Bij hen vindt de IVF plaats in Utrecht, Groningen of Amsterdam en worden de voor onderzoek afgenomen embryonale cellen onderzocht in Maastricht. Met transport PGD worden dezelfde resultaten behaald als met een volledige behandeling in Maastricht. 


\section{Ethische gevoeligheid}

PGD of 'Embryoselectie' zoals deze vorm van diagnostiek de laatste jaren wordt genoemd is vanaf de start ethisch gevoelig geweest. In 1986 dienden Hans Evers en ik een project in bij ZWO, de voorganger van het huidige NWO. Dit kwam wetenschappelijk gezien voor subsidie in aanmerking maar sneuvelde bij de ethische toetsing. Het voorstel om eicellen te bevruchten voor wetenschappelijk onderzoek kon geen genade vinden in de ogen van de Maastrichtse ethische commissie. De tijd was nog niet rijp voor het doen ontstaan van embryo's voor onderzoeksdoeleinden. Wel kwamen er mede door de veroorzaakte commotie eerst de KEMO, de Kerncommissie Ethiek Medisch Onderzoek en later de CCMO, de Centrale commissie Mensgebonden onderzoek als landelijke toetscommissies.

In een tijd dat er openlijk voor werd gepleit om de buitenlandse onderzoeksresultaten af te wachten en deze vervolgens in Maastricht te gaan toepassen hebben Guido de Wert en ik in 1988 in een artikel in het tijdschrift Metamedica de argumenten op een rij gezet waarom het doen ontstaan van embryo's voor onderzoek ethisch aanvaardbaar kan zijn (16). Die argumentatie is nog steeds valide. Waar het gaat om experimenten met embryo's kunnen de volgende 3 standpunten worden ingenomen:

1. Tegen experimenten met embryo's, ongeacht de oorsprong ervan;

2. Voor embryo research, maar uitsluitend met overtollige embryo's;

3. Voor embryo research, ongeacht de oorsprong van de embryo's.

Destijds kwamen we tot de conclusie dat er geen doorslaggevende argumenten zijn om niet voor de derde opvatting te kiezen. Dat dit niet door iedereen onderschreven wordt hangt nadrukkelijk samen met de vraag of het beginsel "eerbied voor het menselijk leven" van toepassing is op embryo's. Het antwoord is ja, maar er zijn twee soorten beschermwaardigheid:

1. Vanaf de bevruchting is er sprake van een persoon, of in ieder geval van een menselijk wezen dat als een persoon behandeld moet worden (absolute beschermwaardigheid).

2. Bij de bevruchting ontstaat een bevruchte eicel die (in de minderheid van de gevallen) het vermogen heeft om uit te groeien tot een persoon (toenemende of betrekkelijke beschermwaardigheid).

Samen met Guido de Wert en vele anderen heb ik altijd de tweede opvatting verdedigd. Dit is ook in lijn met de wet. Wanneer er sprake zou zijn van een absolute beschermwaardigheid zou het gebruik van het spiraaltje moeten worden verboden. Het verhindert immers niet het ontstaan van een embryo maar de innesteling ervan in de baarmoeder.

De Embryowet uit 2002 (17), een van de laatste wetten van het vorige paarse kabinet, bevat een tijdelijk verbod op het doen ontstaan van embryo's voor andere doelen dan het tot stand brengen van een zwangerschap (artikel 24a). Dit betekent dat onderzoek met embryo's zich in ons land moet beperken tot onderzoek waarvoor na IVF afgestane restembryo's kunnen worden gebruikt. Uit de Memorie van Toelichting bij de Embryowet blijkt dat de wetgever destijds geen principieel bezwaar had tegen het doen ontstaan van embryo's voor onderzoek. De regering gaf drie redenen aan om toch een tijdelijk verbod in te stellen:

1 het nog ontbreken van voldoende maatschappelijk draagvlak; 
2 de wens niet teveel uit de pas te lopen met wetgeving in andere Europese landen; 3 de overweging dat het verbod bij de stand van de wetenschap op dat moment geen belangrijke belemmering voor onderzoek leek op te werpen.

De wet bepaalt dat uiterlijk op 1 september 2007 bij Koninklijk Besluit het tijdstip moest worden vastgesteld waarop dit verbod zou vervallen. Tevens is in de wet vastgelegd dat deze op vaste momenten opnieuw beoordeeld moet worden.

De eerste evaluatie vond plaats in 2006. De conclusie was dat er goede redenen waren het tijdelijk verbod spoedig op te heffen. Dat is echter niet gebeurd.

In 2012 heeft een nieuwe evaluatie plaats gevonden. De conclusie is hetzelfde als in 2006 omdat:

1. Het draagvlak is toegenomen;

2. Er meer andere landen zijn waar het verbod is opgeheven;

3. De behoefte aan researchembryo's nog steeds aanwezig is.

Het kabinet moet zich later dit jaar nog uitspreken. Het Tweede Kamerlid Pia Dijkstra van D66 heeft vorige maand een motie ingediend om het verbod op te heffen. Dit betekent dat er veel veranderd is sinds 1988. Maar of dit voldoende is voor een wetswijziging zal afhangen van de onderhandelingen die de regeringspartijen moeten bedrijven om in de Eerste Kamer tot meerderheden te komen. Graag zou ik zien dat ethisch beladen onderwerpen tot vrije kwesties in het parlement worden gemaakt.

\section{Wetenschappelijke samenwerking}

Door een aangepast voorstel in te dienen lukte het toch een projectsubsidie bij ZWO te verwerven voor het embryo-onderzoek. In samenwerking met Dr. Ton Hopman en Prof. Frans Ramaekers ontwikkelde Drs. Edith Coonen een efficiënte FISH-procedure, die uitermate geschikt bleek voor toepassing op het niveau van de individuele cel, zoals vereist voor PGD (18).

Deze methode fungeerde als smeermiddel voor de samenwerking met het Hammersmith Hospital in London, waar in 1990 de eerste klinische toepassing van PGD had plaatsgevonden (19). Het mes sneed aan twee kanten: de in Maastricht ontwikkelde test kon in Londen op humane embryo's in de praktijk worden gebracht en de Maastrichtse medewerkers Edith Coonen en Math Pieters konden zodoende toch ervaring opbouwen met humaan embryonaal materiaal.

Na het aantreden van het eerste paarse kabinet met Minister Borst kwam alles in een stroomversnelling en kon op experimentele basis gestart worden. Maastricht was daarmee na Brussel toch nog een van de eerste PGD-centra op het Europese vasteland.

\section{Voor welke aandoeningen?}

In 1993 hebben een aantal collega's en ik overlegd met Minister Ernst Hirsch Ballin en staatssecretaris Hans Simons over een wettelijke regeling van het medisch onderzoek bij embryo's, waaronder het erfelijkheidsonderzoek bij reageerbuisembryo's. De kranten konden berichten dat het Kabinet akkoord was gegaan met de opstart van PGD. Dit werd slechts toegestaan als het risico aanwezig was dat het embryo een ernstige erfelijke ziekte zou krijgen. Het was in de ogen van de bewindslieden gewenst een lijst op te stellen met aandoeningen die ernstig genoeg waren. In die periode hebben Jelte de Haan en ik meerdere reizen naar het Ministerie van VWS ondernomen om de ambtenaren ervan te overtuigen dat het onmogelijk is geneeskunde te bedrijven op basis van lijsten met aandoeningen die erg genoeg zijn. Het feit dat de onderhandelingen twee jaar duurden zegt al genoeg. Ons standpunt was dat elke aandoening die ernstig genoeg is om tijdens de zwangerschap te worden onderzocht ook in aanmerking kan komen voor 
PGD, mits de kans dat deze zich voordoet voldoende hoog is.

De KEMO was in 1994 van mening dat de eerste klinische toepassingen van PGD vooralsnog beperkt moesten blijven tot ernstige onbehandelbare erfelijke ziekten in verband met de belasting, de onzekerheden en risico's van de nog experimentele methode. Nadat Jos Dreesen was aangesteld, zijn we begonnen met een aantal ziekten die zich bij of kort na de geboorte manifesteerden zoals taaislijmziekte, enkele spierziekten en syndromen die gepaard gaan met verstandelijke beperkingen. Later werden ook ziekten aan het pakket toegevoegd die op latere leeftijd optreden zoals de ziekte van Huntington. In nagenoeg alle gevallen hebben al deze erfelijke ziekten met elkaar gemeen dat de aanwezigheid van de mutatie met bijna $100 \%$ zekerheid voorspelt dat het kind ziek zal worden.

\section{Erfelijke borst- en eierstokkanker}

In een rapport dat in januari 2006 werd uitgebracht door de Gezondheidsraad werd ervoor gepleit ook aandoeningen zoals erfelijke borst- en eierstokkanker toe te laten tot PGD. Bij deze aandoeningen is de kans groot dat het meisje dat het gendefect erft de aandoening krijgt maar deze kans is niet honderd procent. Staatsecretaris Bussemaker stuurde in mei 2008 een brief naar de Tweede Kamer waarin ze aankondigde dat PGD bij erfelijke kanker mocht worden toegepast. In die week ontstond een politiek conflict. Het onderwerp is op vrijdag 30 mei 2008 aan de orde gekomen in de Ministerraad en de uitkomst was dat de brief die al bij de Tweede Kamer lag "hernomen" werd. Het was duidelijk dat de ChristenUnie tegen PGD bij erfelijke borst- en eierstokkanker was, de PvdA voor en het CDA verdeeld tot uit opiniepeilingen bleek dat niet alleen de meerderheid van de Nederlandse bevolking maar ook van de eigen achterban voor was. Enkele dagen later besloten Hans Evers, Guido de Wert en ik, krachtig gesteund door de Raad van Bestuur, ondanks het kabinetsstandpunt toch te beginnen met PGD bij een klein aantal patiënten dat na de publicatie van de brief van de staatssecretaris een toezegging had gekregen. De emoties liepen hoog op. Veel media besteedden aandacht aan PGD. Het begrip embryoselectie vond zijn intrede in Nederland.

De Tweede Kamer hield op 5 juni 2008 een spoeddebat over embryoselectie.

Een kabinetscrisis kon uiteindelijk worden bezworen door aanvullende regelgeving: de 'Regeling PGD' (20) en de instelling van een landelijke 'Richtlijncommissie PGD'. De criteria die in de regeling worden genoemd, betreffen enerzijds de belasting, risico's en kosten van de behandeling en anderzijds de kans op, de ernst en de eventuele behandelingsmogelijkheden van de te voorkomen aandoening.

Als gevolg van de discussie in 2008 is het aantal paren dat verwezen wordt voor embryoselectie aanzienlijk toegenomen, onder andere door aanzienlijk meer verwijzingen voor erfelijke vormen van kanker.

Dit jaar zullen bijna 300 behandelingen plaatsvinden. Er zullen ongeveer 75 kinderen zonder de gevreesde aandoening geboren worden.

\section{De toekomst van de klinische genetica}


Aan het begin van de $21^{\mathrm{e}}$ eeuw is er door de toegenomen technische mogelijkheden en de maatschappelijke acceptatie een enorm optimisme over de bijdrage die kennis van de genetica kan bieden bij tal van vragen op het gebied van de gezondheidszorg. Dit betreft zowel de screening, de diagnostiek als de behandelingsopties.

\section{DNA diagnostiek}

De DNA-diagnostiek is in Nederland tot nu toe altijd verdeeld in veelvoorkomende aandoeningen, die in elk klinisch genetisch centrum worden onderzocht, zoals erfelijke borstkanker en zeldzamere aandoeningen waarvoor de diagnostiek is geconcentreerd in een of enkele centra. Hierover worden jaarlijkse afspraken gemaakt in een landelijk gremium. Door deze werkwijze is Nederland in staat de diagnostiek van veel meer aandoeningen aan te bieden dan het veel grotere Verenigd Koninkrijk. Door de nieuwe manier van werken, de sequencing van het totale genoom, zal het karakter en het aanbod van de diagnostiek in de toekomst echter drastisch veranderen.

\section{Genetische screening}

Genetische screening is systematisch onderzoek naar de aanleg van erfelijke ziekten. Screening op genetische aandoeningen kan op verschillende momenten worden uitgevoerd. Screening voor de zwangerschap is gericht op de tijdige onderkenning van een verhoogde kans op het krijgen van kinderen met een ernstig onbehandelbare aandoening. Genetic counseling kan dan de geboorte van ernstig gehandicapte kinderen voorkomen.

Screening tijdens de zwangerschap kan om dezelfde reden worden uitgevoerd. Behalve het afbreken van de zwangerschap zijn er dan echter geen alternatieven om het risico te beperken.

De pasgeborenen screening is vooral gericht op tijdige opsporing van behandelbare aandoeningen. Momenteel worden pasgeborenen gescreend op een beperkt aantal erfelijke stofwisselingsziekten. Dit betreft uitsluitend aandoeningen die behandelbaar zijn met behulp van dieetmaatregelen of geneesmiddelen. Screening op latere leeftijd betreft het vaststellen van de kans op het krijgen van een aandoening als deze kans via preventieve maatregelen is te beïnvloeden.

Een aanbod van genetisch screening betekent voor de personen uit de doelgroep altijd dat zij beslissingen moeten nemen. Ook een besluit om niet deel te nemen kan gevolgen hebben. Maar ook hier geldt het principe: ieder mens heeft evenveel recht op weten als op niet weten.

\section{Familiescreening}

Familiescreening is verwant aan de andere vormen van screening maar in aantal opzichten ook ervan te onderscheiden. Dit onderzoek worden verricht bij familieleden van patiënten bij wie een genetische aandoening is vastgesteld. Dit kan bijvoorbeeld een erfelijke vorm van kanker betreffen.

De familieleden dienen natuurlijk zelf te bepalen of ze willen weten wat hun erfelijke aanleg voor de betreffende aandoening is. Familiescreening is een van de meest effectieve vormen van preventie van genetische ziekten. 


\section{Behandeling}

Ook waar het gaat om de behandeling van erfelijke aandoeningen is er in de laatste 30 jaar veel veranderd, maar misschien niet zo veel als velen gehoopt of verwacht hadden, zeker wanneer dit de gentherapie betreft.

Onder gentherapie wordt verstaan: het inbrengen van corrigerend DNA of RNA in cellen van een patiënt om een gendefect te corrigeren, of een nieuwe functie aan de cellen toe te voegen waardoor de ziekte wordt opgeheven of bestreden. Gentherapie is in principe acceptabel, zolang de behandeling uitsluitend gericht is op de lichaamscellen van de patiënt. Deze procedures zijn al in de praktijk toegepast bij allerlei proefdieren, maar de efficiëntie van de inbouw en de expressie zijn nog niet voldoende. Bovendien heeft het optreden van kanker voor vertraging gezorgd. Aan manipulatie van de voortplantingscellen kleven nog veel grotere risico's.

\section{Symptomatische behandeling}

Enkele bekende voorbeelden van symptomatische behandeling zijn de toediening van stollingsfactoren bij hemofilie en van insuline bij diabetes mellitus. Maar ook voor meer zeldzame aandoeningen komt steeds vaker therapie beschikbaar. Enkele nieuwe ontwikkelingen betreft de toediening van enzymen die ontbreken bij patiënten met de ziekte van Pompe en de ziekte van Fabry. Dit soort therapieën zal voor steeds meer zeldzame ziekten beschikbaar komen.

In juli 2012 werd in de Nederlandse media gediscussieerd over de kosten van het behandelen van de ziekte van Fabry. Deze kunnen oplopen tot meer dan $€ 500.000$ per patiënt per jaar. Vanwege de hoge kosten en de beperkte effectiviteit heeft het College voor Zorgverzekeringen in de zomer van vorig jaar de vergoeding van de behandeling voor oudere patiënten ter discussie gesteld. Gelukkig heeft Minister Schippers laten weten dat de medicijnen voor beide ziekten dit jaar vergoed blijven worden uit het basispakket. Tevens is zij met beide fabrikanten in onderhandeling getreden over de prijs. Verwacht mag worden dat in de toekomst steeds meer kwetsbare patiëntengroepen in onzekerheid zullen gaan verkeren.

\section{Dieetmaatregelen}

Niet alleen door toediening maar ook door het weglaten van bepaalde stoffen uit de voeding kan het optreden van symptomen worden voorkomen. Klassieke voorbeelden hiervan zijn melk en melkproducten bij galactosemiepatiënten en een phenylalanine arm dieet bij PKU.

\section{Stamceltransplantatie.}

Op termijn mag ook heel verwacht worden van deze methode. Die houdt in dat de zieke cellen vervangen worden door gezonde stamcellen die kunnen worden verkregen uit embryonale cellen maar ook geïnduceerd uit volwassen cellen. Momenteel gebeurt dit bij kanker van het bloedvormende systeem maar verwacht mag worden dat hiervoor ook steeds meer erfelijke aandoeningen in aanmerking komen.

\section{Farmacogenetica}

De farmacogenetica is het aandachtsgebied dat ligt op het grensvlak van de genetica en de farmacologie. Het houdt zich bezig met de vraag waarom sommige mensen wel en andere geen baat hebben bij het gebruik van geneesmiddelen. 
Wanneer patiënten een bepaalde dosis van een geneesmiddel krijgen voorgeschreven zullen de meesten daar heel goed op reageren. Bij anderen zal echter de werking uitblijven of, nog erger, zullen schadelijke bijwerkingen optreden.

De laatste jaren wordt het steeds duidelijker dat er sprake is van individuele gevoeligheid, ongevoeligheid en overgevoeligheid voor geneesmiddelen. Omdat het hierbij om erfelijk bepaalde eigenschappen gaat zal steeds vaker de behandeling van veel patiënten worden voorafgegaan door een genetische test. De vermoedelijke werking of de nevenwerking van de toe te passen geneesmiddelen kan zo voorspeld worden. Op deze manier kan bij steeds meer patiënten dankzij genetische toetsing vooraf zorg op maat worden gegeven.

\section{Samenwerking met Nijmegen}

Wanneer het gaat om de zeer nabije toekomst verheugt het me zeer dat er spoedig sprake zal zijn van een nauwe samenwerking tussen de klinisch genetische centra van Nijmegen en Maastricht. De keuze voor samenwerking is gemaakt voor volumevergroting vanuit een gezamenlijk, compleet diagnostiekaanbod, een sterkere nationale en internationale concurrentiepositie en een grotere slagvaardigheid op het gebied van steeds kostbaardere investeringen. De twee afdelingen, die elkaar goed aanvullen en aanvoelen willen samen naar de top. Dit kan alleen maar met een gezamenlijke leiding. Daarom hoop ik dat mijn collega afdelingshoofd Han Brunner uit Nijmegen op korte termijn wordt benoemd tot mijn opvolger. Ik wens hem van harte proficiat met de onderscheiding die hem vanochtend door de burgemeester van Nijmegen is uitgereikt vanwege zijn benoeming tot Ridder in de Orde van de Nederlandse Leeuw.

Ik wens alle medewerkers van de beide afdelingen in Nijmegen en Maastricht bovendien heel veel succes bij het realiseren van het ambitieuze plan om samen het beste centrum op het gebied van de klinische genetica in Europa te worden. Wanneer ik daarbij kan helpen, ben ik graag beschikbaar.

\section{Museum}

Uit mijn rede mag duidelijk zijn geworden dat de technische ontwikkelingen niet altijd gelijke tred houden met de maatschappelijke. Dit is vaak een gevolg van het feit dat er in de maatschappij sprake is van een kennisachterstand. Deze kan alleen maar doorbroken worden door goede voorlichting. Kennisoverdracht en voorlichting kunnen op veel verschillende manieren plaatsvinden. Ik hoop hier ook in de toekomst een bijdrage aan te kunnen blijven leveren in het Museum voor Familiegeschiedenis in Eijsden. Dit museum zal in het Karel de Grote jaar 2014 de deuren openen. Het zal zich richten op de genealogie, de heraldiek, maar zeker ook op de evolutie van de mens. Vanwege het laatste ben ik er als voorzitter van de Stichting Eugene Dubois bij betrokken geraakt. Eugene Dubois, de ontdekker van de missing link in de evolutie van aap naar mens is geboren op 200 meter afstand van het museum.

In het museum zullen de overeenkomsten en verschillen tussen en binnen families worden uitgelegd aan de hand van het molecuul dat in de genetica centraal staat: het DNA. Zo hoop ik een nieuwe invulling te gaan geven aan het begrip Dezen en Genen. Ik hoop u daarom allen in de toekomst in Eijsden te mogen begroeten en dit verklaart het vraagteken achter de titel van mijn afscheidsrede. 


\section{Dankwoord}

Omdat ik het voorrecht heb gehad mijn afdeling, het ziekenhuis en de universiteit zo lang te mogen en kunnen dienen wil ik graag besluiten met het uitspreken van een welgemeend dankwoord. Bij de aanvang hiervan wil ik mijn verontschuldigingen aanbieden aan allen die ik nu uit tijdgebrek niet kan gaan noemen.

Allereerst wil ik graag mijn beide grote leermeesters in de genetica bedanken. In Nijmegen was dat Lee T. Douglas die mij tijdens mijn hoofdvak liet kennismaken met de fruitvlieg Drosophila melanogaster. In Leiden heeft Peter Pearson mij de kans geboden om zijn eerste promovendus te worden en te switchen naar de humane genetica.

Vervolgens wil ik graag alle bestuurders van de Universiteit Maastricht en de voormalige faculteiten geneeskunde en gezondheidswetenschappen bedanken voor het in mij gestelde vertrouwen als hoogleraar, vakgroepvoorzitter en decaan van de transnationale universiteit. Tevens voor het voorrecht om dit afscheid te mogen vieren in dit theater.

Met evenveel dankbaarheid denk ik terug aan de vele kansen die ik heb gekregen van het bestuur van het academisch ziekenhuis Maastricht en speciaal de onvoorwaardelijke steun en de financiering van de ontwikkeling van de PGD uit het academisch budget.

Vervolgens het bestuur van de Stichting Klinische Genetica Limburg, dat mij heeft aangesteld als directeur en vervolgens alle vrijheid heeft gegeven. Speciaal wil ik in dit verband de voorzitter en secretaris noemen, Frans Smits en Lou Brans Brabant. Beste Frans en Lou, zonder jullie was ik nooit zover gekomen, zeker niet op de fiets.

Marja van Dieijen-Visser en Jan Nijhuis, de beide bestuurders van de eenheden waar we na de integratie als afdeling Klinische Genetica bij zijn ondergebracht, de RVE Laboratoria en Beeldvorming en de RVE Erfelijkheid, Voortplanting en het Kind wil ik graag bedanken voor de uiterst plezierige en collegiale samenwerking.

Als representanten van de onderzoeksscholen wil ik speciaal Jelte de Haan en Frans Ramaekers noemen. Ons matrixmodel zorgt ervoor dat de belangen van de schools en de vakgroepen haaks op elkaar staan. Toch zijn we er samen meestal goed uitgekomen.

De unithoofden Connie Stumpel, John Engelen, Jorgen Bierau en Bert Smeets dank ik dat ik bij het besturen van de afdeling zoveel kon en mocht delegeren. Ook alle andere medewerkers ben ik enorm veel dank verschuldigd. Dat geldt speciaal voor mijn beschermengelen, Judith, Ingeborg, Wilma, Wies en Ingrid, maar ook voor Peter, Jan, Jo, Renée en Dimitri.

Beste Hans Evers en Guido de Wert. In de afgelopen 30 jaar hebben we samen enorm veel meegemaakt, zowel binnen de faculteit en het ziekenhuis, maar ook buiten Maastricht en zeker ook in Europees ESHRE verband. Ik hoop dat we ook na vandaag nog vaak als 3 musketiers samen ten strijde kunnen trekken.

Christine de Die, John Dumoulin, Jos Dreesen, Edith Coonen en alle andere leden van de Werkgroep PGD. We hebben enorm veel bereikt, maar er is ook nog genoeg te doen. Dat kan ik met een gerust hart aan jullie overlaten en ik wens Christine heel veel succes als hoogleraar. 
De contacten met de medewerkers van de transportcentra Utrecht, Groningen en Amsterdam en de collega's uit Brussel en Straatsburg hebben telkens weer voor nieuwe inspiratie gezorgd. Ik hoop dat we elkaar ook na vandaag nog vaak zullen ontmoeten.

De PGD is steeds geïntroduceerd in overleg met de patiënten organisaties, zoals de Nederlandse Cystic Fibrosis Stichting, Vereniging Spierziekten Nederland, de Haemophilie vereniging, de Huntington Vereniging, Borstkanker Vereniging Nederland, de VSOP en andere. Heel hartelijk dank aan alle bestuursleden en contactpersonen.

Ook de samenwerking met mijn collega hoogleraren en de andere medewerkers van de vakgroep Genetica en Celbiologie, van de secties en van het zeer recent toegevoegde IPHG heb ik erg genoten. Het is jammer dat ik vandaag geen tijd heb gehad om in te gaan op de vele boeiende ontwikkelingen in jullie secties en stil te staan bij de prestaties die jullie hebben geleverd op het gebied van onderzoek en onderwijs. Ik wens Jan Glatz, die het voorzitterschap heeft overgenomen, veel succes.

Graag hoop ik na vandaag met mijn bloedeigen Dezen en Genen: Kirsten en Simon, Tobias en Patricia en de kleinkinderen Louisa en Finn, nog enkele hoofdstukken aan onze familiegeschiedenis toe te voegen.

Lieve José, je bent onmisbaar en al meer dan 45 jaar een grote steun voor mij. Vanaf nu zal ik er zeker meer voor jou zijn. We zullen beslist niet achter de geraniums gaan zitten maar wel de bloemetjes buiten zetten en ervan gaan genieten.

Tot slot wil ik alle andere collega's, familieleden, vrienden en andere aanwezigen bedanken. Dat jullie hier in zo grote getale aanwezig zijn geweest heeft een onvergetelijke indruk op mij gemaakt.

Ik heb gezegd. 


\section{Referenties}

1. Watson JD, Crick FH. Molecular structure of nucleic acids; a structure for deoxyribose nucleic acid. Nature. 1953 Apr 25;171(4356):737-8.

2. Tjio JH, Levan A. The chromosome number of man. Hereditas 1956; 42: 1-6.

3. Lejeune J, Gahthier M, Turpin R. Les chromosomes humains en culture de tissus. C R Hebd Seances Acad Sci. 1959 Jan 26;248(4):602-603.

4. de Ligt J, Willemsen MH, van Bon BW, Kleefstra T, Yntema HG, Kroes T, Vulto-van Silfhout AT, Koolen DA, de Vries P, Gilissen C, del Rosario M, Hoischen A, Scheffer $\mathrm{H}$, de Vries BB, Brunner HG, Veltman JA, Vissers LE. Diagnostic exome sequencing in persons with severe intellectual disability. N Engl J Med. 2012 Nov 15;367(20):1921-9.

5. www.omim.org: Online Mendelian Inheritance in Man.

6. Gezondheidsraad, 1977. Advies intake Genetic Counseling, Rijswijk.

7. Fuchs F, Freiesleben E, Knudsen EE, Riis P. Antenatal detection of hereditary diseases. Acta Genet Stat Med. 1956-1957;6(2):261-3.

8. Galjaard $\mathrm{H}$, Wallenburg H. Prenatale diagnostiek van aangeboren afwijkingen. In: De voortplanting van de mens. Bussum (1973).

9. Wet Afbreking Zwangerschap, 1 mei 1981.

10. Brambati B, Simoni G. Diagnosis of fetal trisomy 21 in first trimester. Lancet. 1983 Mar 12;1(8324):586.

11. Nicolaides K. Screening for fetal aneuploidies at 11 to 13 weeks. Prenat Diagn. 2011 Jan;31(1):7-15.

12. Mersy E, Smits L, van Winden L, de Die-Smulders C, The South-East Netherlands NIPT Consortium, Paulussen A, Macville M, Coumans A, Frints S. Noninvasive detection of fetal trisomy 21: systematic review and report of quality and outcomes of diagnostic accuracy studies performed between 1997 and 2012. Hum Reprod Update. 2013

13. Steptoe P, Edwards R. Birth after the reimplantation of a human embryo. Lancet. 1978 Aug 12;2(8085):366. 
14. Smeenk J, Kremer J. Landelijke IVF-cijfers 1996-2011. (http:// www.nvog.nl/ voorlichting/ IVF-resultaten).

15. Ministerie van VWS: Planningsbesluit klinisch genetisch onderzoek en erfelijkheidsadvisering (2003).

16. De Wert G, Geraedts J. IVF, pre- embryo-research en ethiek. Metamedica. 1988. 67, 106-23.

17. Wet van 20 juni 2002, houdende regels inzake handelingen met geslachtscellen en embryo's (Embryowet).

18. Coonen E, Hopman A, Geraedts J, Ramaekers F. Application of in-situ hybridization techniques to study human preimplantation embryos: a review. Hum Reprod Update. 1998 Mar-Apr;4(2):135-52.

19. Handyside A, Kontogianni E, Hardy K, Winston R. Pregnancies from biopsied human preimplantation embryos sexed by Y-specific DNA amplification. Nature. 1990 Apr 19;344(6268):768-70.

20. Ministerie van VWS: Regeling preïmplantatie genetische diagnostiek (PGD) van 5 maart 2009. 